\title{
An Actor-oriented Approach to Rights in Development
}

\section{Celestine Nyamu-Musembi*}

\section{Introduction}

Rights are shaped through actual struggles informed by people's own understandings of to what they are justly entitled. Looking for the meaning of rights from the perspective of those claiming them transforms defined normative parameters of human rights debates, questions established conceptual categories and expands the range of claims that are validated as rights. Drawing out these "actor-oriented perspectives" on rights can shed new light on some key debates that have gone on among human rights legal practitioners and scholars such as the tensions between universalist and cultural relativist approaches to rights; between group rights and individual rights; between civil and political rights, and economic, social and cultural rights; and around the accountability of non-state actors in upholding rights. Bottom-up actor-oriented perspectives shaped by specific human rights struggles question the premises of these debates, by bringing the perspective of actors engaged in struggles for rights to the fore. These perspectives are at the core of a rights-based approach to development.

This article will demonstrate how focusing on specific struggles for rights can challenge the parameters of these debates. Further, this article will contextualise a rights-based approach to development within an actor-orientated perspective in terms of particular struggles around rights, drawing both from accounts of these struggles and critical responses to the debates outlined above to point to the possibility of an actor-oriented perspective on rights. Finally, this article will highlight some of the implications of an actororiented perspective in terms of putting rightsbased approaches into practice in development.

\section{What does an "actor-oriented" perspective mean?}

By an "actor-oriented" perspective, I mean an understanding of human rights needs and priorities that is informed by the concrete experiences of the particular actors involved in and who stand to gain directly from, the struggles in question. My understanding of an actor-oriented perspective is drawn in part from legal literature that does not necessarily position itself within the human rights tradition, but which calls for an evaluation of legal principles in terms of their concrete effects in a social setting, rather than in terms of the conceptual coherence of abstract principles. ${ }^{1}$ This literature goes beyond a call for attention to context to an emphasis on consequences for less powerful groups and/or individuals in society. To quote one of the authors, Joseph Singer:

When we ask ourselves whether a social or legal practice works, we must ask ourselves, 'works for whom?' Who benefits and who loses from existing political, economic, and legal structures? (Singer 1990: 1841)

Such an approach explicitly acknowledges the reality of power differences and hierarchical relationships in society and therefore points to the need to look beyond abstract formal equality principles to the effect of those principles in entrenching or challenging hierarchy - from the perspective of the subordinated (Matsuda 1990: 1768; Minow and Spelman 1990: 1650).

When people ask the question 'works for whom?' and translate this question into action, they change the terms of institutionalised understandings of rights and make the meaning of rights real in their own context. They use an otherwise legalistic discourse of rights in a transformative manner that translates it into an effective challenge against power inequalities. They shift the parameters of the discourse and expand the possibilities for action. 


\subsection{Rights-based approaches to development ${ }^{2}$}

A rights-based approach to development, at its core, is predicated on the principle that development should result in empowerment of socially and economically disadvantaged groups (Ghai 2001). An underlying proposition is that a society that is committed to achieving social justice must implement social and economic rights. This seems commonplace on the face of it, but is proved controversial by the lack of political will in making this simple idea a reality (Ghai 2001: 49).

The rights-based approach suggests an integrated view of sustenance (economic and social rights) and freedom (civil and political rights) as complementary; each one is necessary for the full realisation of the other. Again, a fact that should be self-evident but one which has been obscured by Cold War politics and decades of controversy within the human rights movement. Naila Kabeer (2002) writes of this linkage from the perspective of the purpose of rights. The purpose of rights is to ensure "freedom of action". Viewed from this perspective, both freedom from coercion (civil and political rights) and the freedom to access material resources serve the complementary purposes of protection and promotion of the ability to act. None is adequate without the other. Since the 1995 Copenhagen Declaration on Social Development, which seeks to use the framework of rights to achieve goals such as poverty eradication, there has been increasing focus on rights-based approaches to development as a means to bridge the gap between freedom and sustenance.

The Human Development Report 2000 had as its theme this linkage between human rights and human development, emphasising that although these two fields have followed separate disciplinary paths, they share the same goals: securing freedom for a life of dignity and expanding people's choices and opportunities (UNDP 2000). A rights-based approach adds an element of accountability and culpability; an ethical/moral dimension to development. It therefore, demands a shift from viewing poverty eradication as a development goal to viewing it as a matter of social justice; as the realisation of a right and the fulfilment of a duty. ${ }^{3}$

Within the framework of a rights-based approach to development, non-governmental organisations (NGOs) and bilateral programmes committed to its implementation have come up with lists of rights they regard as basic, which cut across the spectrum of economic, social, cultural, civil and political rights. ${ }^{4}$ However, systematic inquiry needs to be conducted among these organisations to generate answers to the question "how does the adoption of a rights-based approach make us "do development" differently?'5 For Medha Patkar of the Narmada Bachao Andolan movement, for instance, a rightsbased approach will only be effective and transformative, if it changes the starting point of development altogether. In the context of development projects that threaten to displace people (such as damming the Narmada river in India), the inquiry must begin from the rights of the communities whose livelihood is tied to the river, rather than from a "risk assessment" which immediately limits the inquiry to compensation packages. A "rights assessment" will raise the fundamental question of the right to participate in the very process of development planning in the first place (see Blackburn et al., this issue). ${ }^{6}$

\section{Actor-informed perspectives on key debates in international human rights}

Focusing on four key issues that have been central to international human rights debates, this section demonstrates that a focus on concrete struggles leads to a questioning of the underlying assumptions and changes the terms of these debates.

\subsection{Universality vs cultural relativism}

Do human rights principles provide a universal standard to be applied uniformly, or are they contingent on social context? Are human rights norms universal by virtue of a common humanity, or is the concept of human rights inherently defined by the specific cultural context? This debate has characterised the post-World War II human rights movement since the enactment of its founding document: the Universal Declaration of Human Rights (UDHR), 1948 and continues to be intense. To summarise briefly, universalists' arguments make a normative claim that human rights should provide a universal standard because rights inhere in every human person by virtue of simply being human. Rights flow from the inherent dignity of every human person. Rights are not given by the sovereign and therefore the sovereign cannot take them away. Nor are rights pegged to social status or stratification based on age, gender, or caste. Since rights flow from the inherent dignity of the human person, they are 
therefore not contingent on particularities such as political, social, economic or cultural context.

The universalist position is encoded in international human rights documents such as the 1993 Vienna Declaration on Human Rights, adopted at the first UN Conference on Human Rights. The preamble to the Declaration states that 'all human rights derive from the dignity and worth inherent in the human person' and that the UDHR 'constitutes a common standard of achievement for all peoples and all nations'. The second category of universalist arguments is the formalist argument that since most states have ratified and agreed to be legally bound by international human rights law, then human rights standards are universal. In addition, some argue, the UDHR, though simply a declaration that is not legally binding is such a widely accepted landmark instrument in human rights that it has (or parts of it have) become customary international law (Steiner and Alston 2000: 367). Customary international law refers to norms that have evolved from state practice over time, which bind even those states that have not entered into specific treaties on those aspects of international law: in this case, human rights.

Radical cultural relativist arguments are at the other end of the spectrum from normative and formalist universalist arguments. The radical cultural relativist arguments hold that there can be no transcendent idea of rights. Radical cultural relativism views culture as 'the sole source of the validity of a moral right or rule' (Wilson 1997: 2). Therefore international human rights norms reflect a particular cultural viewpoint, a Western one. A good example of radical cultural relativism is the statement that the American Anthropological Association (AAA) issued in reaction to the draft UDHR in 1947. The AAA cast doubt on the UDHR's claim to represent a universal perspective. It stated:

How can the proposed Declaration be applicable to all human beings and not be a statement of rights conceived only in terms of the values prevalent in the countries of Western Europe and America? ... Standards and values are relative to the culture from which they derive so that any attempt to formulate postulates that grow out of the beliefs or moral codes of one culture must to that extent detract from the applicability of any Declaration of Human Rights to mankind as a whole. (AAA 1947: 539)
Examples of features that the AAA regarded as being of a typically Western worldview are the centrality of the individual as opposed to the community (discussed below) and the emphasis on rights as opposed to duties.

In the arena of state practice of international law, cultural relativism is expressed in the reservations that various states have made to some human rights instruments. The UN Convention on the Elimination of All Forms of Discrimination Against Women (CEDAW) registers the highest number of reservations, most of which relate to the provisions that stipulate equality in family relations and state obligation to reform customs and practices that discriminate against women. ${ }^{7}$ The phrasing of the reservations show clearly that the states concerned see these provisions as inherently contradictory to their cultural and or religious values. For example, Bangladesh, Tunisia, Libya and other Muslim countries cite conflicts with Islamic law as the reason for their reservations, and give no indication that this situation could change to permit withdrawal of the reservations any time in the future.

\section{Actor-informed perspectives that question the terms of the universality-vs-cultural relativism debate}

Mahmood Mamdani challenges the assumptions underlying the debate on universality (specifically the debate on whether rights are of a Western origin) by arguing that rights are defined by struggle and rights struggles are born of experiences of deprivation and oppression.

Without the experience of sickness, there can be no idea of health. And without the fact of oppression, there can be no practice of resistance and no notion of rights ... Wherever there was (and is) oppression - and Europe had no monopoly over oppression in history - there must come into being a conception of rights. (Mamdani 1989: 1-2)

Viewed from this perspective, human rights are both universal and particular: universal because the experience of resistance to oppression is shared among subjugated groups the world over, but also particular because resistance is shaped in response to the peculiarities of the relevant social context.

The extreme positions in the universalist-vscultural relativist have also been criticised for 
obscuring manifestations of local understandings of rights, "vernacularisation" of rights, in the words of Sally Engle Merry (Merry 1997). She uses ethnographic data drawn from Hawaiian struggles for independence to show that even though the discourse of human rights is based on "Western liberal-legalist ideas", when specific struggles in non-Western societies utilise the discourse in framing their demands, the concept is reinterpreted and transformed. This transformation is a two-way process of incorporation of local understandings and the addition of global discourses, and it is this two-way process that she refers to as "legal vernacularisation".

A similar challenge has come from accounts that undertake a situated analysis of how people actually live in a context of legal and cultural pluralism ${ }^{8}$ and strategically draw from both their cultural or religious norms and formal rights regimes in dealing with real life situations. Both cultural norms and formal rights regimes provide opportunities and challenges in dealing with specific situations. The lines are not so clear cut in reality, which rules out a clear cut demarcation placing the blame for human rights violations on culture and positing universal human rights principles embodied in formal laws as the solution (Nyamu 2000; Nhlapo 1995; WLSA 1995).

\subsection{Individual or group rights?}

One of the arguments made in the AAA statement of 1947 and other radical cultural relativist critiques is that human rights discourse downplays the importance of community. It therefore seeks to impose an individualist model of rights that is at odds with non-Western ways of life. This same emphasis is present in the constitutions of countries that have adopted the liberal state framework. Is there space for group-based claims in the liberal individualist formulation of rights? Conversely, how are individual liberties to be protected in the context of group rights? These questions have been the subject of debate in the broader conversation between liberals and communitarians. The former conceptualise people/citizens as self-interested autonomous individuals while the latter view individual identity as being defined through relations with others and embedded in community. A good summary of the various arguments in this broader debate is contained in Mulhall and Swift (1992), so I will not go into detail here. In addition,
Jones and Gaventa (2002) address the liberalcommunitarian debate briefly in discussing the various conceptions of citizenship.

There are some international human rights documents that embody human rights whose holders are groups as well as individuals. An early example is the 1948 Convention on the Prevention and Punishment of the Crime of Genocide. The 1981 African Charter on Human and Peoples' Rights designates some rights as individual (dignity, recognition of legal status as a person, right to receive information, freedom of association and movement, right to work, etc.), and others as "peoples"' rights. Peoples' rights include the right to existence and self-determination, right to economic, social and cultural development, and the right to a general satisfactory environment favourable to their development.

\section{Perspectives that challenge the antagonistic view of individual and community rights}

One struggle that has changed the terms of the debate on individual and collective rights is the struggle for the rights of indigenous peoples. In the early stages of its engagement with the international human rights arena, the struggle had to overcome immense ideological opposition (mainly from the USA and Australia) to the use of the term "peoples" (plural) in the draft UN Declaration on the Rights of Indigenous Peoples (1994). The plural form "peoples", suggests group rights as opposed to the rights of aggregated individuals. The declaration is still being discussed by a Working Group of the UN Sub-commission on the Promotion and Protection of Human Rights.

Like the African Charter, it incorporates both rights regarded as belonging individually to members of indigenous communities (e.g. nationality, life, physical and mental integrity, liberty, security) and rights regarded as collective (e.g. right to live freely as distinct peoples). Some rights are phrased as both individual and collective. These include freedom from genocide and other forms of violence (such as the removal of children from their homes), deprivation of cultural values and identities, imposed assimilation and dispossession of their lands.

New developments have made it quite clear that there are some rights claims that can only be conceived of in collective terms. For instance, in arguing for compensation to indigenous communities for use of their knowledge in 
medicine, developing new plant varieties, or films and other forms of art based on oral traditions, it would be impossible to ascribe ownership to particular individuals. These claims have been framed in terms of packages or programmes that benefit the community as a collective (Posey 1990). Thus, collective action by indigenous communities around these emerging issues calls into question the rigid distinction between individual and community in thinking about human rights.

In addition to the movement for indigenous peoples' rights, there have been other calls for a conception of rights that does not treat collective rights, such as the claims of family and kinship groups, as inherently antagonistic to individual rights. Contrary to the dominant tendency in liberal human rights discourse, which is to present statecitizen relations in abstracted individualist terms, people are constantly negotiating between an internal moral system (shaped by factors such as culture and religion, and represented by institutions such as kinship) and the formal legal regime of the liberal state (Khare 1998: 199). Far from subsuming individual concerns under community interests, "situated analyses of rights" point to people's own experience of these concerns and interests as overlapping and intertwined, sometimes in harmony and sometimes in tension.

One example is drawn from Khare's ethnographic work among "untouchable" women in a Lucknow neighbourhood in India (Khare 1998). ${ }^{9}$ These women's perception of primary or fundamental rights integrated a vision for the individual and the community. They spoke of the most important right as the "right to survive", which consists of access to "food, clothing, housing, education, and secure life, but not at the expense of [their] personal and community honour' (Khare 1998: 200). Concern about personal insult went hand in hand with concern about humiliation of their parents and husbands, as did concern for physical violence, including violence committed by those same parents and husbands (Khare 1998: 201, 212). This latter concern points to the reality of simultaneous harmony and tension between individual and group rights. This is the lived reality.

Khare's account of the experiences of untouchable women reveals a more general point on the relationship between individual and group rights. When status as a member of a particular group (e.g. low caste) is so central to how one is defined and treated in a particular social context, it leaves little room to speak of such an individual's rights without addressing the broader issue of the group's status as a rights-holding community.

Adopting the perspective of people situated within the reality of this complex web of relationships regulated primarily by social norms changes not only the way we think about human rights, but the way we "do" human rights. This has certainly been the case for activists engaged in community-based human rights work with Muslim women, and for advocates of Islamic family law reform. A group of women's human rights activists from various Islamic backgrounds have developed a Manual for Women's Human Rights Education in Muslim Societies (Afkhami and Vaziri 1996). The manual covers a broad range of "rights situations" such as rights within the family, autonomy in familyplanning decisions, rights to education and employment, and rights to political participation. What makes the manual different from conventional human rights education manuals is that its interactive and interpretive exercises interweave excerpts from international human rights agreements with verses from the Qur'an, shari'a rules, stories, idioms and personal experiences.

Taking as an example the session on women's rights and responsibilities within the family: the session begins with an exercise whereby participants give their views on where rights come from, which opens a discussion on the family as a source of rights, and/or what role the family plays in protecting or denying rights. Then follows an exercise on "talking to the men in your family", which teases out differences and similarities in the way various women in the group relate with their male family members. An exercise on "negotiating your rights and responsibilities within your family" focuses on a woman's freedom to choose whom and when to marry. The exercise is facilitated through the story of a woman named Leila, her father and the man to whom she has been betrothed. A series of questions based on the scenario culminate in a reflection on two verses from the Qur'an and article 16(2) of the Universal Declaration of Human Rights (UDHR) ${ }^{10}$ which invites the participants' comments on what aspects of their cultural and religious experience support women's rights within the family (Afkhami and Vaziri 1996: 5-9).

Recognition of the reality of community and of plural moral orders also forces us to think more 
broadly about sites for human rights engagement and come up with more innovative strategies. For instance, access to formal types of remedies under statutes and constitutional bills of rights may be placed beyond the reach of weaker social groups due to factors such as cost, bias or perception of the formal system as far removed from people's dayto-day lives. In addition, the social cost of pursuing formal remedies may be prohibitive, as in the case of a widow deprived of access to inheritance by her in-laws. She knows that she has legal standing to apply for the necessary letters to administer the estate, and that she has legal rights to the property as a widow, which she could enforce in court. But it is also in her interest and that of her children to maintain good relations with her in-laws, and this restrains her from taking legal action.

Scenarios such as these have led to activist strategies and scholarship that engage with the norms that sustain and regulate these relationships (such as kinship) "on their own terms". This engagement with community norms (also referred to as customary law) has prompted attention to micro-level forums, such as intra-family and community-based dispute-resolution processes and made them sites for human rights struggles. These forums play a key role in enabling or constraining people's ability to claim whatever rights are available to them under custom, national laws or international human rights principles (Griffiths 1997 and 2001; Nyamu 2000 and 2002; Hellum 1999; Hirsch 1998; Stewart 1998).

The strategies adopted or proposed by activists and scholars engaging with these customary fora include:

- enforcing obligations recognised under the relevant customary law or community norms;

- gathering empirical evidence of flexibility and variation in customary practice and its responsiveness to changing social circumstances, in order to challenge rigid, hierarchical and ahistorical assertions of custom;

- invoking general ideas of justice and fairness within a community; and

- challenging the disingenuous use of custom to preserve inequitable social arrangements.

The challenge is to craft a legal framework of rights and citizenship that adjudicates fairly in the complex reality of harmony and tension between individual and group claims. One that does not disregard the community context in which people are embedded, but at the same time does not legitimise a narrow definition of personhood that is based on status in hierarchical social relationships. ${ }^{11}$ The latter would thereby deny the very agency that rights and citizenship should enable (Kabeer 2002: 20).

\subsection{Indivisibility of rights: hierarchy between civil-political and economic-social rights}

In practice, people obviously do not experience rights or their deprivation in a bifurcated manner, distinguishing between rights of a civil-political nature and rights of an economic-social nature. In an organised protest in 1987, street vendors in Ahmedabad, Gujarat, expressed their struggle as being about "dignity and daily bread". Police harassment, irregular allocation of trading spaces, city laws enacted without public participation, uneven distribution of resource among neighbourhoods were all integrated (IHRIP and Asian Forum for Human Rights and Development 2000: v; Rowbotham and Mitter 1994).

The founding document of international human rights, the UDHR, makes no distinction between rights of a civil-political nature (e.g. fair trial, freedom of movement, association, expression) and rights of an economic-social nature (e.g. adequate standard of living, right to work). It provides for rights in both categories. The debate on hierarchy between civil and political rights on the one hand, and economic, social and cultural rights on the other originated in the post-UDHR attempt to draw up a single binding charter of rights, and became a defining feature of the international human rights discourse throughout the Cold War era. The conflict resulted in the enactment of two separate human rights covenants: the International Covenant on Civil and Political Rights (ICCPR) and the International Covenant on Economic, Social and Cultural Rights (ICESCR) in 1966.

On the one hand, the Soviet Union and states allied to it argued for the primacy of economic and social rights. Civil and political rights such as the freedom of speech would have no meaning for people lacking in basic necessities such as food and shelter. They dismissed civil and political rights as Western ideology that had no relevance to societies with different political structures.

Western European and North American states 
and their allies on the other hand, viewed civil and political rights as the only rights of a truly "legal" nature, as opposed to economic and social demands which were not justiciable (i.e. could not be enforced in court against the state) (Steiner and Alston 2000: 237). According to this position, the recognition of economic and social claims as rights would obscure the philosophical coherence of human rights.

Some recent academic accounts still continue to contest the "rights status" of economic and social concerns and their relevance to discussions on citizenship rights. The exclusion of "so-called social rights" from a study on the link between social movement activities and the enjoyment of citizenship rights was explained as follows:

Whatever the virtues of these rights (and there are many), they do not qualify as integral to the discourse of rights, and therefore cannot serve the purposes of a comparative study of citizenship. (Foweraker and Landman 1997: 14)

The authors go on to argue that while civil and political rights are universal and amenable to formal expression in the rule of law, "social rights" are:

fiscally constricted and require distributional decisions [and therefore] they are best described not as equal and universal rights but as "conditional opportunities" [more realizable in the developed welfare capitalist states]. (Foweraker and Landman 1997: 15)

All rights require the allocation of resources, including civil and political rights that are presumed in this quote to be free of distributional consequences. For instance, guaranteeing the right to a free trial and the right to vote require resources, as do rights to health and education.

There have been some significant attempts to institutionalise the idea that all human rights are interlinked; that rights guaranteeing political freedom and civil liberties are dependent on rights guaranteeing sustenance or economic and social development and vice versa. One example is the 1986 UN Declaration on the Right to Development. The declaration recognises that development is a comprehensive economic, social, cultural and political process, whose purpose is the improvement of the well-being of all individuals on the basis of meaningful participation and fair distribution of the benefits of development.

By the time of the UN Conference on Human Rights held Vienna in 1993, the idea of interdependence of rights was being popularised increasingly in the post-Cold War human rights circles. Paragraph 5 of the 1993 Vienna Declaration states that '[A]ll human rights are universal, indivisible, interdependent and interrelated' and calls on the international community to treat all rights fairly and equally, on the same footing and with the same emphasis.

Citizenship must be an active condition of struggling to make rights real. (Phillips 1991)

The discussion so far bears witness to the relevance of this statement. Specific social movement struggles at particular times have been crucial in moving the discourse and practice of human rights beyond the impasse of conventional debates, and shaping actor-oriented perspectives. These struggles have transformed the defined normative parameters of human rights, questioned established categories, expanded the range of claims that could be characterised as rights and in some cases altered institutional structures. ${ }^{12}$ The insights arising from these social movements cut across all of the debates discussed above. Indigenous peoples' struggles have transformed approaches to group rights as well as broadened the arena of rights to cover issues of ownership of knowledge and a more robust interpretation of the right to a healthy environment. Communities' challenges to multinational corporations continue to expand spaces for holding powerful non-state actors accountable, both through formal legal processes (such as public interest law suits) and informal nonbinding measures such as codes of conduct, "citizen juries" and street protests. Demands for "dignity and daily bread" reject the compartmentalisation of rights into the political and economic spheres. Rights claims in a rapidly changing world continue to expand the rubric of rights to cover new concerns such as knowledge rights.

\section{Conclusion}

The final section highlights some of the key emerging implications for taking an actor-orientated approach to rights in practice, particularly in the context of development research and practice. 


\subsection{Situated citizenship}

First, there is need to incorporate pluralistic approaches to citizenship and rights, which capture the everyday experiences of citizenship as mediated by factors such as gender, ethnicity, caste and kinship structure. Such a holistic analysis of citizenship and rights highlights how these expressions of diverse and overlapping identities function simultaneously as forces of inclusion and exclusion (Kabeer 2002).

The discussion on universality and cultural relativism, as well as the debate on harmony and tension between individual and group rights provide a departure point for thinking about how "situated citizenship", like actor-orientated rights, can change the parameters of debate. While paying attention to the particular, as defined by gender, ethnicity, religion, etc., we should not lose sight of the relevance of formal citizenship and how the mutual interaction between "situated" and formal citizenship enables or constrains agency. It is crucial to ask, for instance, how formal state law (public) has validated and reinforced structures of inequality that have come to be viewed largely as resulting from or being dictated by (private) custom or religion.

\subsection{Non-hierarchical but interdependent rights}

The lesson from this debate is to guard against a dichotomous and hierarchical model of rights, while at the same time being attentive to the reality that at times the realisation of one right is contingent on the existence of another. Some researchers in the IDS-based Development Research Centre on Citizenship, Participation and Accountability have already encountered this reality in their work. For instance, research by the Society for Participatory Research in Asia (PRIA-India) among nomadic communities in Rajasthan set out to explore their understandings of citizenship so as to work (in conjunction with a local NGO) toward enabling their participation in local governance.

It soon became clear that the right to participate in the Panchayat (local government) was tied to residence; accessing the benefits guaranteed to them as tribal people depended on possession of the official ration card, which too requires one to have a fixed address. Being nomadic they are perceived as having no fixed residence, and therefore they have neither ration card nor representation in local governance structures. The NGO is therefore undertaking a campaign for land as the priority right that establishes the basis for other rights claims. ${ }^{13}$

Using rights-based approaches in practice requires asking open questions about how people articulate rights claims in specific situations, rather than focusing on which types of rights are important and how they reinforce or weaken each other. The open question is more likely to bring out the complex overlap between demands for rights as "things" and demands for the power to make decisions concerning the "things" (participation).

\subsection{Conceptualising accountability for human rights}

In order for rights to translate into reality, a broadened understanding of human rights accountability that goes beyond state structures to broader engagement with private sector institutions and civil society organisations is necessary. Practices seeking to expand the accountability of non-state actors have explored options beyond conventional legal channels (Garvey and Newell 2004). Some of the options, such as citizen juries and civil society participation in the design and verification of corporate codes of conduct exist on or outside the margins of legal obligation, but play an important role where few legal avenues exist. What implications do such tools have for a politicised conception of rights that offers a real challenge to power? How do we ensure that they do not simply become avenues for voice that do not translate into any real influence?

This article has explored how recasting rights through actual struggles can shed new light on existing debates about rights. An actor-orientated perspective on rights-based approaches privileges the experiences of poor and marginalised groups and their own understandings of rights, but without denying the importance of formal sources of rights. The approach enables the pushing of the boundaries of formal legality when this is necessary for justice. It also highlights the importance of a more situated approach to citizenship, where rights are interdependent, and where a range of accountability mechanisms function to hold institutions responsible. While an actor-orientated perspective on rights-based approaches exposes the complexities of using rights in practice, it also holds greater possibilities for leading to positive change. 


\section{Notes}

* This article is adapted and abridged from NyamuMusembi (2002), 'Towards an actor-orientated perspective on rights', IDS Working Paper 169, Brighton: Institute of Development Studies.

1. See, e.g. scholarly work in the "critical pragmatic" framework: Joseph Singer, 'Property and coercion in federal Indian law: the conflict between critical and complacent pragmatism'; Margaret Radin, 'The pragmatist and the feminist'; Mari Matsuda, 'Pragmatism modified and the false consciousness problem'; Martha Minow and Elizabeth Spelman, 'In context' - all in Southern California Law Review (1990).

2. For a discussion of the historical context and various institutions' perspectives on rights-based approaches to development, see Cornwall and Nyamu-Musembi, this issue.

3. Amartya Sen's work has been influential in making a link between "development" and "freedom" and his views influenced the conceptual premise of the Human Development Report 2000 (Sen 1994; 1999).

4. See, e.g. Caroline Moser and Andy Norton (2001), To Claim Our Rights. Moser and Norton develop a functional classification of rights into three categories: rights necessary for survival and dignified living (e.g. life, social protection, work, privacy); rights and freedoms for human dignity, creativity and intellectual and spiritual development (e.g. education, expression, association, political participation); and rights necessary for liberty and physical security (e.g. physical integrity, freedom from torture, freedom from arbitrary arrest, freedom from slavery). The rights listed in each category fall both within civil and political and economic, social and cultural rights. Development NGOs such as Oxfam and ActionAid have participated in the drawing up of a charter of ten basic rights, which integrate political and socio-economic rights.

5. This inquiry is the subject of the Institute of Development Studies (IDS) Participation Group project on 'Linking Rights and Participation', some of which is reported in this issue of the IDS Bulletin (Miller et al. pages 31 and 52; Cornwall and Nyamu-Musembi; Musyoki and NyamuMusembi)

6. Medha Patkar, 'Mobilising for social justice', seminar presentation at IDS, Sussex, 16 May 2002

7. CEDAW articles 2(f), 5(a) (calling on states to reform customs, practices and stereotypes that reinforce women's inferior status) and 16 (which calls upon states to take legal and other measures to ensure equality in family relations).
8. Most post-colonial societies are characterised by "classic" legal pluralism, which refers to the co-existence of formal laws derived from the colonial encounter with the West, and laws based on custom and religion, which have been incorporated into the legal system (Merry 1988; Griffiths 1986).

9. Ethnographic method is particularly useful in unearthing "actor perspectives" because it "exposes us to people's changing moral-jural reasoning while dealing with situations in real life' (Khare 1998: 199).

10. Article 16(2) of the UDHR guarantees the right to marry and equal rights between men and women in marriage.

11. States whose constitutions bar people from challenging discrimination suffered on account of the application of religious or customary family law (e.g. Kenya, Zambia and Zimbabwe) are examples of legal frameworks that fail to adjudicate fairly in instances of tension between individual and community interests. Examples of legal frameworks that try to do so fairly include the constitutions of Ghana, Malawi, Uganda and South Africa, which recognise the operation of religious and customary laws subject to the fundamental rights guaranteed to all in the constitution. For further reading on the issue of balancing between individual rights and the recognition of cultural or religious norms, see Nyamu (2000).

12. Resistance to the Sardar Sarovar project to dam the Narmada river in India led to the establishment of an Inspections Panel within the World Bank in 1993 to oversee projects' compliance with the Bank's own Operating Procedures. The panel is still operational to date. It receives complaints from any individual or groups who have suffered as a result of such non-compliance and investigates them. Information on the Inspection Panel, including up-to-date summaries of requests received can be viewed on the bank's website. In the Narmada project, the Bank's guidelines on resettlement and rehabilitation had been disregarded in the planning and implementation of the project (Rajagopal 2000; Fisher 1995).

13. Nandini Sen and Mandakini Pant, PRIA, presentation at meeting of Development Research Centre on Citizenship, Participation and Accountability Working Group on Meanings and Expressions of Rights, Dhaka, Bangladesh, 31 January 2002. 


\section{References}

AAA (American Anthropological Association), 1947, 'Statement on human rights', American Anthropologist, Vol 49: 539

Afkhami, M. and Vaziri, H., 1996, Claiming Our Rights: A Manual for Women's Human Rights Education in Muslim Societies, Bethesda, MD, USA: Sisterhood is Global Institute

Fisher, W. (ed.), 1995, Toward Sustainable Development: Struggling Over India's Narmada River, Armonk, N.Y.: M.E. Sharpe

Foweraker, J. and Landman T., 1997, Citizenship Rights and Social Movements: A Comparative and Statistical Analysis, Oxford: Oxford University Press

Garvey, N. and Newell, P., 2004, 'Corporate accountability to the poor? Assessing the effectiveness of community-based strategies', IDS Working Paper 227, Brighton: Institute of Development Studies

Ghai, Y., 2001, 'Human rights and social development: toward democratization and social justice', UNRISD Democracy, Governance and Human Rights Programme Paper 5

Ghai, Y., 1998, Asian Human Rights Charter: A People's Charter, Hong Kong: Asian Human Rights Commission

Griffiths, A., 2001, 'Gendering culture: towards a plural perspective on Kwena women's rights', in J. Cowan, M. Dembour and R. Wilson (eds), Culture and Rights: Anthropological Perspectives, Cambridge: Cambridge University Press

Griffiths, A., 1997, In the Shadow of Marriage: Gender and Justice in an African Community, Chicago: University of Chicago Press

Griffiths, A., 1986, 'What is legal pluralism?', Journal of Legal Pluralism and Unofficial Law, Vol 24: 1

Hellum, A., 1999, Women's Human Rights and Legal Pluralism in Africa: Mixed Norms and Identities in Infertility Management in Zimbabwe, Tano Aschehoug: Mond Books

Hirsch, S., 1998, Pronouncing and Persevering: Gender and the Discourses of Disputing in an African Islamic Court, Chicago: University of Chicago Press

International Human Rights Internship Program (IHRIP) and Asian Forum for Human Rights and Development, 2000, Circle of Rights: Economic, Social and Cultural Rights Activism: A Training Resource, Washington, D.C.: International Human Rights Internship Program
Jones, E. and Gaventa, J., 2002, 'Concepts of citizenship: a review', IDS Development Bibliography 19, Brighton: Institute of Development Studies

Kabeer, N., 2002, 'Citizenship, affiliation and exclusion: perspectives from the South', IDS Bulletin, Vol 33 No 2: 12

Khare, R.S., 1998, 'Elusive social justice, distant human rights: untouchable women's struggles and dilemmas in changing India', in M. Anderson and S. Guha (eds), Changing Concepts of Rights and Justice in South Asia, Delhi: Oxford University Press

Mamdani, M., 1989, 'Social movements and constitutionalism in the African context', Centre for Basic Research Working Paper 2, Kampala, Uganda

Matsuda, M., 1990, 'Pragmatism modified and the false consciousness problem', Southern California Law Review, Vol 63: 1763

Merry, S.E., 1997, 'Legal pluralism and transnational culture: the Ka Ho'okolokolonui Kanaka Maoli Tribunal, Hawai'i, 1993', in R. Wilson (ed.), Human Rights, Culture and Context: Anthropological Perspectives, London: Pluto Press Merry, S.E., 1988, 'Legal pluralism', Law and Society Review, Vol 22: 869

Minow, M. and Spelman, E., 1990, 'In context', Southern California Law Review, Vol 63: 1597

Moser, C. and Norton, A., 2001, To Claim Our Rights: Livelihood Security, Human Rights and Sustainable Development, London: Overseas Development Institute

Mulhall, S. and Swift, A., 1992 Liberals and Communitarians, Oxford: Blackwell

Nhlapo, T., 1995, 'Cultural diversity, human rights and the family in contemporary Africa: lessons from the South African constitutional debate', International Journal of Law and the Family, Vol 9: 208

Nyamu, C., 2000, 'How should human rights and development respond to cultural legitimization of gender hierarchy in developing countries?', Harvard International Law Journal, Vol 41: 381

Nyamu-Musembi, C., 2002, 'Are local norms and practices fences or pathways? The example of women's property rights', in A. An-Na'im (ed.), Cultural Transformation and Human Rights in Africa, London: Zed Books

Phillips, A., 1991, 'Citizenship and feminist theory', in G. Andrews (ed.), Citizenship, London: Lawrence and Wishart: 76-77 
Posey, D., 1990, 'Intellectual property rights and just compensation for indigenous knowledge', Anthropology Today, Vol 6: 13

Radin, M., 1990 'The pragmatist and the feminist', Southern California Law Review, Vol 63: 1699

Rajagopal, B., 2000, 'From resistance to renewal: the third world, social movements and the expansion of international institutions', Harvard International Law Journal, Vol 41: 531

Rowbotham, S. and Mitter, S. (eds), 1994, Dignity and Daily Bread: New Forms of Economic Organizing Among Poor Women in the Third World and the First, London: Routledge

Sen, A., 1999, Development as Freedom, Oxford: Oxford University Press

Sen, A., 1994, 'Freedoms and needs', The New Republic, 10 Jan, 17: 31

Singer, J., 1990, 'Property and coercion in federal Indian law: the conflict between critical and complacent pragmatism', Southern California Law Review, Vol 63: 1821
Steiner, H. and Alston, P., 2000, International Human Rights in Context: Law, Politics, Morals, Oxford: Oxford University Press

Stewart, J., 1998, 'Why I Can't Teach Customary Law', in J. Eekelaar and T. Nhlapo (eds), The Changing of Family: Family Forms and Family Law, Oxford: Hart Publishing

UNDP (United Nations Development Programme), 2000, Human Development Report 2000, New York: Oxford University Press

Wilson, R., 1997 'Human rights, culture and context: an introduction', in R. Wilson (ed.), Human Rights, Culture and Context: Anthropological Perspectives, London: Pluto Press Women \& Law in Southern Africa (WLSA) Research and Educational Trust, 1995, 'Beyond research: WLSA in action', WLSA Working Paper 10, Harare, Zimbabwe 